\title{
The computational analysis of the crack width of beams reinforced with CFRP and steel bars
}

\author{
Kinga Brózda ${ }^{1, *}$, and Jacek Selejdak ${ }^{1}$ \\ ${ }^{1}$ Department of Concrete Structures and Geotechnics, Faculty of Civil Engineering, Czestochowa \\ University of Technology, Poland
}

\begin{abstract}
The aim of the paper is to explain the particular problems related to the use of FRP reinforcement in bending beams. The paper compares the aspect of Serviceability Limit State (SLS) of simply supported concrete beams reinforced with Carbon Fiber Reinforced Polymer (CFRP) bars and three various types of steel bars (the steel grades are 35G2Y, 20G2VY-b and B500SP). The computational analysis of change in crack width under the influence of various level of service live load was investigated. The calculations of beam reinforced with FRP bars was based on Italian design guideline (CNR-DT 203/2006) and the conventional reinforced concrete beams (RC) were analysed in accordance with the European standard Eurocode 2 (EN 1992-1-1:2004).
\end{abstract}

\section{Introduction}

The low corrosion resistance of the steel reinforcement is a typical limitation of RC (reinforced concrete) structures, especially if the structures are exposed to the aggressive environmental factors [1-7]. To avoid such problems, the alternative FRP (Fiber Reinforced Polymer) rebar could be used as an internal longitudinal flexural reinforcement. This relatively new solution provides high protection against corrosion damage of RC structures. In additional, very good physical and mechanical properties of the FRP as low density and what is connected with it the low dead load, low thermal expansion coefficient, high tensile strength-to-weight ratio and very good fatigue properties cause the FRP an attractive alternative for steel reinforcement [7-11]. Unfortunately, the disadvantage of this solution is low value of modulus of elasticity of FRP materials, which has a significant impact on Serviceability Limit State (SLS) as deflection or crack width [11-14].

\section{Computational analysis}

The main purpose of the paper is an assessment of the impact of load intensity to the crack width increasing. The computational analysis concerned the beams reinforced with steel and polymer rebar. The crack width increasing of beams reinforced with selected steel rebar and CFRP bar were compared.

\footnotetext{
*Corresponding author: kbrozda@bud.pcz.pl
} 


\subsection{Assumed calculation model}

The calculations of rectangular-shaped, simply supported beams were done. The static scheme and localization of reinforcement $A_{f}$ are presented in the Fig. 1. The length of the span was assumed as $L_{\mathrm{eff}}=4.0 \mathrm{~m}$ and the dimensions of cross-section are: $b=0.18 \mathrm{~m}$, $h=0.35 \mathrm{~m}$. The investigated beams were under various static stress of service live load $w_{\mathrm{L}}=\{0.5 ; 2.0 ; 3.5 ; 5.0 ; 6.5 ; 8.0 ; 9.5 ; 11.0\} \mathrm{kN} / \mathrm{m}$, dead load $w_{\mathrm{D}}=1.58 \mathrm{kN} / \mathrm{m}$ and service dead load of $w_{\mathrm{SDL}}=3.0 \mathrm{kN} / \mathrm{m}$.

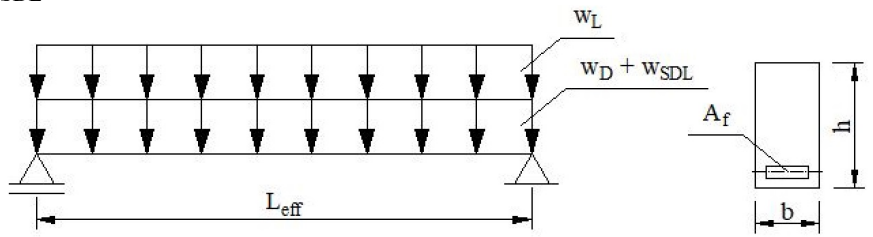

Fig. 1. The assumed static scheme and cross-section of beams.

The beams were reinforced with $4 \Phi 12$ of polymer rebar CFRF (Carbon Fiber Reinforced Polymer) with a relatively high modulus of elasticity and "C" steel grade reinforcement: 35G2Y, 20G2VY-b and B500SP, which have the highest values of tensile strength. The concrete is specified by $\mathrm{C} 20 / 25$ compressive strength class: the characteristic compressive strength $f_{\text {ck }}=20 \mathrm{MPa}$, the mean value of axial tensile strength of concrete $f_{\mathrm{ctm}}=2.2 \mathrm{MPa}$, the ultimate compressive strain in the concrete $\varepsilon_{\mathrm{cu} 3}=0.0035$, the modulus of elasticity $E_{\mathrm{cm}}=30 \cdot 10^{3} \mathrm{MPa}$. The concrete cover thickness is assumed as $c_{\text {nom }}=35 \mathrm{~mm}$. The material characteristics of rebar are presented in the Table 1 . The strength properties of the polymer rebar are reported by the manufacturer's material data [15].

Table 1. The material characteristics of reinforcement $[15,16]$.

\begin{tabular}{|c|c|c|c|c|}
\hline $\begin{array}{c}\text { Type of } \\
\text { rebar }\end{array}$ & $\begin{array}{c}\text { The characteristic } \\
\text { yield strength [MPa] }\end{array}$ & $\begin{array}{c}\text { The characteristic } \\
\text { tensile strength [MPa] }\end{array}$ & $\begin{array}{c}\text { The modulus of } \\
\text { elasticity [MPa] }\end{array}$ & $\begin{array}{c}\text { The design } \\
\text { strain [-] }\end{array}$ \\
\hline CFRP & - & 2300 & $130 \cdot 10^{3}$ & 0.018 \\
\hline 35G2Y & 410 & 550 & \multirow{2}{*}{$200 \cdot 10^{3}$} & \multirow{2}{*}{$>0.0675$} \\
\cline { 1 - 3 } 20G2VY-b & 490 & 590 & & \\
\cline { 1 - 3 } B500SP & 500 & 575 & \\
\cline { 1 - 3 }
\end{tabular}

\subsection{Results}

The results of calculated beams are presented in the Table 2 .

Table 2. The crack widths $w_{\mathrm{k}}$ depend on type of used bars and live load level $w_{\mathrm{L}}$.

\begin{tabular}{|c|c|c|c|c|c|c|c|c|}
\hline The live load level $[\mathrm{kN} / \mathrm{m}]$ & 0.5 & 2.0 & 3.5 & 5.0 & 6.5 & 8.0 & 9.5 & 11.0 \\
\hline Type of rebar & \multicolumn{7}{|c|}{$w_{\mathrm{k}}[\mathrm{mm}]$} \\
\hline CFRP & 0.202 & 0.217 & 0.225 & 0.229 & 0.232 & 0.234 & 0.235 & 0.236 \\
\hline 35G2Y & 0.133 & 0.144 & 0.156 & 0.193 & 0.231 & 0.262 & 0.290 & 0.316 \\
\hline 20G2VY-b & 0.151 & 0.163 & 0.174 & 0.197 & 0.240 & 0.276 & 0.307 & 0.334 \\
\hline B500SP & 0.155 & 0.167 & 0.178 & 0.197 & 0.242 & 0.278 & 0.310 & 0.338 \\
\hline
\end{tabular}

In the computational analysis, the calculations of beams reinforced with steel rebar were done in accordance with the EC2 standard [16]. There is no available standard to design the polymer reinforcement. However, the guidelines for design the structural elements reinforced with FRP bars were elaborated as a result of work experience of researchers and designers. The calculations the crack width of beams reinforced with CFRP was done in accordance with the Italian design recommendations [17], due to the similarity to EC2 standard [16]. 
The crack width $w_{\mathrm{k}}$ of the beams reinforced with steel rebar (Fig. 2) depending on the value of the mean strain allowing under the relevant combination of loads for the effects of tension stiffening, shrinkage, etc., seems to increase linearly. Assuming according to the EC2 standard that limitation of the crack width $w_{k . l i m}$ is equal $0.4 \mathrm{~mm}$, none of investigated beams exceeded the limit value.

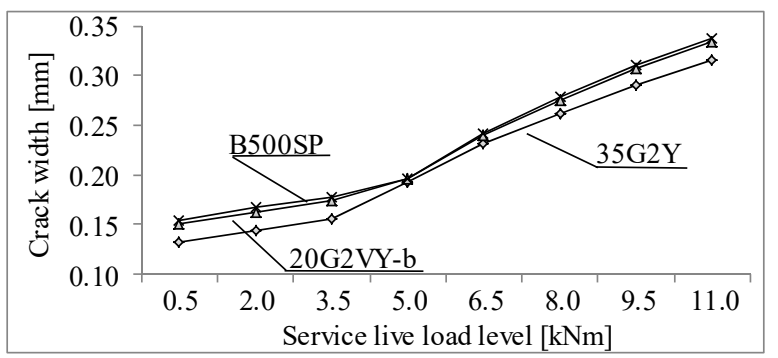

Fig. 2. The crack widths of steel rebar depending on service live load level.

In contrast to steel reinforcement, the $w_{k}$ of beam reinforced with CFRP increases logarithmically. It means that the crack width increase is more dynamically at the initial load. The graph in the Fig. 3 presents the relation between crack width and service live load level.

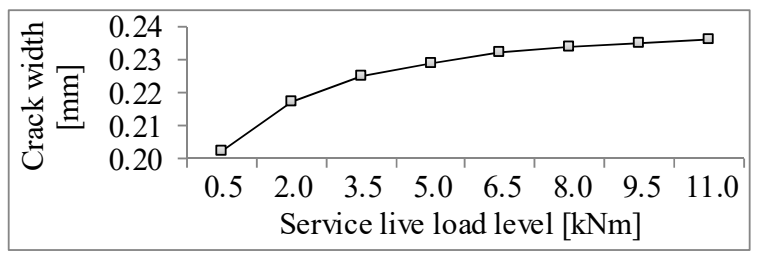

Fig. 3. The crack widths of CFRP rebar depending on service live load level.

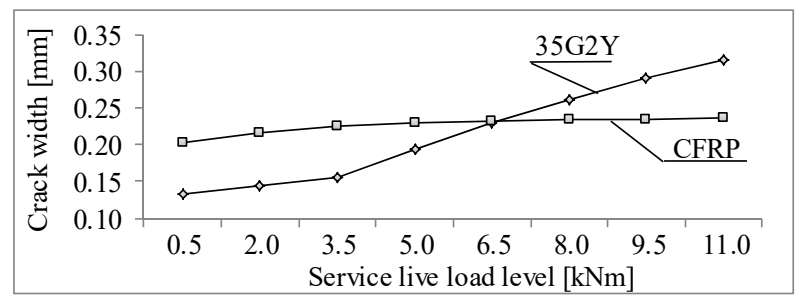

Fig. 4. The comparison of crack widths of CFRP and 35G2Y rebar.

In the Fig. 4 the increase of the crack widths of beams reinforced with CFRP and steel $35 \mathrm{G} 2 \mathrm{Y}$ rebar were combined and compared. The steel $35 \mathrm{G} 2 \mathrm{Y}$ were selected because the achieved values of crack width were the lowest (Fig. 2). As shown in the graph (Fig. 4) the increase of the crack width due to level of the service live load is more dynamic in case of the steel reinforcement. The component lines intersect almost at the point of $6.5 \mathrm{kN} \cdot \mathrm{m}$ value. It means that above that level of load the beam reinforced with CFRP rebar has higher flexural capacity (due to higher tensile strength then steel's) and lower crack width. This phenomena makes that beam more effective in high levels of loading.

\section{Summary}

The crack widths depend on various level of load of the beams reinforced with steel and CFRP rebar were analysed and compared. During the computational analysis based on 
available standards and recommendations [16, 17], the high influence of relatively low modulus of elasticity on the SLS were concluded. Moreover, the differences between graphs of the crack width increase were noticed. The relationship between service live load level and crack widths of beams reinforced with steel rebar is linear, while the graph of CFRP reinforced beam increases logarithmically. It leads to conclusion that the CFRP reinforcement is more effective when the service live load achieves level higher than $6.5 \mathrm{kN} \cdot \mathrm{m}$. That phenomena in combination with very good flexural capacity due to the high value of the tensile strength, makes the CFRP rebar an attractive solution for RC structures which are exposed to aggressive environmental factors.

However, the only selected issue of the Serviceability Limit State was examined. It is recommended to limit the SLS deflections. The high impact of the low value of modulus of elasticity on the increased deflection is expected.

\section{References}

1. T. Lipinski, 16th Inter. Sci. Conf. Eng. for Rural Devel., (1069-1074, 2017)

2. I. Pliszka, N. Radek, Proc. Eng., 192, 707-12 (2017)

3. C. Barris, L. Torres, C. Miàs, I. Vilanova, J.of Civ. Eng. Man., 18(6), 843-857 (2012)

4. A. Szczotok, J. Nawrocki, J. Pietraszek, Arch. of Metal. Mat., 62(2), 587-593 (2017)

5. J. Selejdak, R. Ulewicz, M. Ingaldi, 23rd International Conference on Metallurgy and Materials, Conference Proceedings (Brno, Czech Rep., 1882-1888, 2014)

6. J. Pietraszek, A. Szczotok, N. Radek, Arch. Metall. Mater., 62, 235 (2017)

7. H.A. Abdalla, Composite Structures, 56, 63-71 (2002)

8. K. Brózda, J. Selejdak, Production Engineering Archives, 12(3), 2-4 (2016)

9. K. Brózda, J. Selejdak, P. Koteš, Proc. Eng., 192, 64-68 (2016)

10. C. Bywalski, M. Drzazga, M. Kamiński, Build. Mat., 6, 72-73 (2014)

11. K. Brózda, M. Major, J. Selejdak, 23th Int. Conf. EM2017 (218-221, 2017)

12. R.J. Gravina, S.T. Smith, Eng. Struct., 30, 2370-2380 (2008)

13. H. Toutanji, Y. Deng, Constr. Build. Mat., 17, 69-74 (2003)

14. J. Pietraszek, E. Skrzypczak-Pietraszek, Adv. Mat. Res.-Switz., 874, 151-155 (2014)

15. Sireg Geotech S.r.l. prod. data sheet, available at: www.sireggeotech.it/en (22.12.2016)

16. Design of concrete structures. General rules and rules for buildings (EN 1992-1$1: 2004)$

17. Guide for the Design Cons. of RC Struct. Reinf. with FRP Bars (CNR-DT 203/2006) 